\title{
PENGAJARAN APRESIASI SASTRA DI SEKOLAH LANJUTAN ATAS \\ KEAKRABAN GURU-MURID DENGAN KARYA SASTRA
}

Oleh: I Wayan Sugita ${ }^{1}$

\begin{abstract}
The high school is the last level in the framework of basic education, which prepares students to continue their education or to college, or to the largest number work in the society. Especially if we remember this second possibility, that possibility can not be avoided by the majority of high school graduates as a result of the state of our education today, then we should be really concerned. These concerns are not just demanding to pitch our chest, but and even more demanding of ourselves efforts to bridge the gaps between reality and expectations of education
\end{abstract}

Keywords: Appreciation of Literature Teaching, Teachers and Students

\begin{abstract}
Abstrak
Sekolah lanjutan atas merupakan jenjang terakhir dalam rangka pendidikan dasar, yang mempersiapkan para siswa untuk atau melanjutkan pendidikan ke perguruan tinggi, atau bagi jumlah terbesar terjun ke dalam masyarakat. Terutama jika kita mengingat kemungkinan kedua inilah, yaitu kemungkinan yang tidak dapat dihindari oleh sebagian besar lulusan sekolah lanjutan atas sebagai akibat keadaan pendidikan kita dewasa ini, maka seharusnya kita benar-benar prihatin. Keprihatinan ini tidak sekedar menuntut ke lapangan dada kita, melainkan dan terlebih lagi menuntut dari diri kita upaya-upaya untuk menjembatani jurang-jurang pemisah antara kenyataan dan harapanpendidikan

\section{Kata Kunci: Pengajaran Apresiasi Sastra, Guru dan Murid}

\section{Pendahuluan}

Pada tingkat lanjutan atas, apresiasi sastra tidak lagi bertolak dari patokan suka atau tidak suka. Tingkat demikian, lazimnya ditemukan di antara anak didik sekolah dasar yang kegiatan apresiasinyamasih primitif; artinya, masih sangat diayomi unsur keterlibatan emosional. Di sekolah lanjutan atas, kegiatan apresiasi telah berpijak pada minat budaya dan sosial.Artinya, keterlibatan emosional sudah sangat banyak

digantikan oleh daya pengamatan yang peka dan kritis terhadap lingkungannya.

Jika seorang siswa sekolah dasar sudah puas dengan mengidentifikasikan dirinya dengan lingkungan terdekatnya seperti ayah-bunda, keluarga, dan guru mereka di sekolah maka seorang siswa sekolah lanjutan atas memproyeksikan dirinya pada lingkungan dalam arti yang luas. Sebenarnya, kegiatan itu dilakukanuntukmengukur dirinyasendiri.Akan
\end{abstract}

${ }^{1}$.Dr. I Wayan Sugita, S,S.,M.Si dosen Pengajar Program Pasca Sarjana IHDN Denpasar 
tetapi, dalam kenyataan sehari-hari yang tampak atau terdengar adalah justru sebaliknya mereka mengukurdan menilai lingkungan diluar dirinya. Sikap dan kegiatan inilah yang biasanya sangat "memusingkan" pada pendidik, bahkan tidak jarang memojokkan para guru (dan orang tua) sebab selagi masih belajar di sekolah, makhluk yang dipakai sebagai layar proyeksi langsung adalah sang guru. Tidak jarang para siswa seakan menuntut dari gurunya untuk bertindak sebagai wasit, atau yang lebih parah lagi, sebagai hakim yang harus memutuskan mana yang benar dan mana yang salah.

Sehubungan dengan pengajaran apresiasi sastra di sekolah lanjutan atas maka sekurangkurangnya tiga masalah dapat dicatat, yaitu:

1. Pengajaran apresiasi sastra merupakan bagian dari pengajaran bahasa Indonesia. Selain itu, materi pengajaran lebih menekankan hafalan istilah dan pengertian sastra serta pengenalan sejarah sastra dalam jalur kronologi semata daripada mengakrabkan diri dengan karya sastra itu sendiri sembari mendalami makna sejarah bagi perkembangan sastra.

2. Beban pengajaran seorang guru bahasa Indonesia menjadi semakin membentuk lingkaran setan karena tuntutan pengajaran bahasa tidaklah sama dengan tuntutan pengajaran sastra. Jika yang pertama lebih mengarah pada ketrampilan, maka yang kedua mensyaratkan keakraban yang berlapang dada dalam rengkuhan pengetahuan yang melampaui batas-batas kebahasaan.

3. Pilihan materi pengajaran dihadapkan dengan kenyataan yang menentang kebijaksanaan pendidikan yang telah digariskan. Artinya, penambahan ragam sastra yang terjadi dalam masyarakat berkecepatan jauh lebih tinggi daripada kemungkinan-kemungkinan penyesuaian kurikulum pendidikan yang sudah sarat dengan berbagaihambatan.
Dalam keadaan sebagaimana dinyatakan di atas, guru harus melaksanakan tugas sehariharinya tanpa dapat ditunda. Pertanyaan demi pertanyaan diajukan oleh para siswa di dalam kelasnya, yang harus ditanggapi segera pula. Apa yang sebaliknya dilakukan dalam keadaan demikian?

\section{Ragam Sastra dan Sikap Pembaca}

Istilah ragam dalam kertas kerja ini tidak menunjuk pada pengertian genre, yang lazimnya diartikan sebagai bentuk sastra, yaitu prosa, puisi, dan drama. Ragam disini menunjuk pada keanekaan jenis karya tulis yang oleh orang kebanyakan disebut sastra: cerita pendek, cerita bersambung, sajak, novel atau cerita rekaan, baik yang berupa buku, stensilan, dicetak dalam majalah yang juga macam-macam ragamnyamaupun yang dicetak dalam lembaran khusus surat kabar, di koran atau selebaran yang ditempel di dinding. Dengan kata lain, masyarakat umum menganggap Sitti Nurbaya, Belenggu, cintaku di Kampus Biru, dan Ali Topan sama-sama 'sastra'.

Sebenarnya, keanekaragaman 'sastra' demikian bukanlah sesuatu yang baru dalam sejarah sastra di Indonesia: Didirikannya, Commissie voor de Inlandsche School en Volkslectuur antara lain bertujuan untuk membendung pengaruh "bacaan liar". Pada tahun 30-an ada jenis sastra yang digolongkan sebagai "roman picisan", walau penamaan itu tidak ada hubungannya dengan harga bukubuku demikian. Pada tahun 60-an terjadi kehingaran sekitar "novel porno". Dalam dasawarsa terakhir ini bermunculan "novel pop".

Sebagai karya yang menggunakan bahasa sebagai alatnya dan yang mewujudkan dalam bentuk tertulis lepas dari soal genre atau ragam dan tempat penulisan maka sekalian ragam sastra yang ada itu merupakan hasil yang di satu pihak tidak dapat diubah sebagai kenyataan sosial budaya masyarakat yang melahirkannya; 
di lain pihak, karya tersebut mendiri sekalipun bagai anak yatim piatu tak berbapak, tak beribu walau sebelum kelahirannya ada pengarang atau penyair yang menciptakannya. Bukankah karya itu ada di mana-mana tanpa didampingi oleh penciptanya? Dengan kata lain, dalam kedudukannya sebagai karya tulis yang mandiri demikian, maka ia sepenuhnya terlempar ke dalam wewenang pembacanya untuk dipahami atau tidak dipahami, untuk dihargai atau tidak dihargai, untuk dinilai atau dibiarkan sendiri dalam ke yatim piatuannya yang otonom.

Dipandang dari kenyataan itu kiranya secara agak ekstrim dapat dikatakan, betapa sastra/non-sastranya suatu karya sangat bergantung pada mampu atau tidaknya seorang pembaca untuk menikmatinya. Jelasnya, seorang pembaca yang kurang akrab dengan sastra akan sukar menikmati karya sastra sehingga sukar pula dapat menilainya dengan memadai. Pembaca yang pengalaman bacanya sedikit, misalnya, baik dalam hal sastra maupun dalam bidang-bidang lainnya akan terbentur pada berbagai hambatan dalam kegiatan apresiasi dibandingkan dengan pembaca yang pengalaman bacanya lebih banyak, lebih luas. Sebagai contoh dapat dikemukakan ilustrasi berikut.

Seorang pembaca yang memupuk tradisi dan pengalaman bacanya terbatas pada apa yang disebutkan dalam buku Pokok dan Tokoh, misalnya, akan berkembang menjadi penikmat yang kegiatan apresiasinya terutama terbina menuruti "tradisi" buku-buku terbitan Balai Pustaka dan katakan1 ah Pustaka Jaya, yaitu penerbit masa kini yang "wibawanya" setaraf dengan "wibawa" Balai Pustaka di tahun 20-an. Pembaca demikian akan berkecenderungan untuk menolak menemukan "keindahan" yang diungkapkan secara "lain" daripada buku-buku yang pernah dibacanya sekalipun sikap demikian sangat mungkin tidak disadari sepenuhnya. Dengan kata lain, pembinaan kegiatan apresiasinya yang terbatas akan pula membatasi kemungkinan pengembangan kemampuan apresiatifnya bagi karya-karya yang "menyimpang" dari tradisi dan pengalaman bacanya. Ia kurang dapat menghargai karya Danarto yang terhimpun dalam kumpulan cerpennya berjudul Godlob, misalnya. Atau, ia akan menganggap tokoh Sri dalam Pada Sebuah Kapal karya Nh. Dini sebagai keterlaluan gamblangnya, sangat "tidak bersifat Timur". Selain itu, sangat besar kemungkinannya ia menolak karya Iwan Simatupang yang berjudul Ziarah, misalnya, dengan kekesalan yang sama seperti halnya ia mungkin akan menolak karya Putu Wijaya yang berjudul Telegram. Dari pembaca demikian kita tak dapat mengharapkan keterbukaan apresiasinya untuk menikmati novel remaja Arjuna Mencari Cinta karya Yudhistira Ardi Nugraha, sedangkan Sok Nyentrik atau Cowok Komersil karya Eddy D. Iskandar akan dinilainya sebagai lebih gawat lagi.

Dipandang dari sudut "hak" dan "wewenang" pembaca untuk menjatuhkan penilaiannya pada karya yang dibacanya, sikap demikian tentu tidak dapat diganggu gugat. Akan tetapi, jika sikap demikian dipaksakan pada anak didiknya, apalagi di tingkat lanjutan atas ataupun di perguruan tinggi, maka keadaan demikian namanya parah. Kemungkinan terciptanya keadaan seperti itu bukannya tak ada karena bukankah guru dianggap "berwibawa" oleh anak didiknya?

Kecenderungan para pendidik pada umumnya adalah menyandarkan sikap dan penilaian pada suatu pendapat biasanya dalam bentuk buku sejarah sastra yang dianggap mempunyai "wibawa". Buku Pokok dan Tokoh karya Prof. Dr. A. Teeuw (serta versi bahasa Inggrisnya Modern Indonesian Literature), buku-buku susunan H.B. Jassin seperti Angkatan '66, dan buku Ajip Rosidi yang berjudul Ikhtisar Sejarah Sastra Indonesia merupakan buku-buku yang "dipegang" para pendidik, baik di tingkat sekolah maupun 
perguruan tinggi. Sikap demikian pada dasarnya tidaklah dapat dikatakan sirma sekali keliru, asal....

Kita harus pertama-tama menyadari bahwa tiap kurun waktu mempunyai alasan-alasan dan kebutuhan-kebutuhan tersendiri. Kedua, tata nilai dari satu kurun waktu tertentu tidaklah harus diwariskan ke kurun waktu berikutnya. Ketiga, sebagai pembaca kita seyogyanya mampu mengembangkan diri seirama dengan derap perkembangan yang berlangsung. Terakhir, pada hemat saya yang sangat penting adalah menyadari sepenuhnya penalaran yang ada di balik segalanya itu: Mengapatimbul ragam itu di suatu kurun tertentu? Mengapa tata nilai tampaknya bergeser atau bahan berubah? Mengapa kita perlu mengembangkan diri seirama dengan derap perkembangan yang ada? Pertanyaan-pertanyaan demikian harus mendahului tiap keputusan kita dalam menjatuhkan pilihan, buku mana atau pendapat siapa yang akan kita anggap sebagai yang "berwibawa". Ini kalau yang dipersoalkan hanyalah sekedar buku pegangan dalam pengajaran. Ini, kalau yang dipersoalkan hanyalah sekedar memiliki "buku putih" yang akan dipakai sebagai sumber untuk mengumumkan kata putus dalam menjalankan tugas sehari-hari kita sebagai wasit atau hakim di dalam jam pengajaran apresiasi sastra.

Kiranya tak perlu diuraikan disini bahwa sikap demikian tidaklah memadai dalam menyelenggarakan pengajaran sastra kepada siswa lanjutan atas, apalagi di perguruan tinggi. Kalau pun ada yang "berhasil" menerapkannya, maka "keberhasilan" demikian patut kiranya diragukan: Barangkali gurunya otoriter; barangkali para siswanya tidak kritis; barangkali baik guru maupun siswanya tidak menyadari hakikat sastra; barangkali seluruh konsep pendidikan yang dipraktekkan hanyalah sekedar mengejar "target" yang telah ditetapkan; barangkali baik guru maupun siswanya sama-sama "miskin" dalam pengalaman sastra mereka. Dari sekian banyak kata barangkali, yang paling mendasar adalah kebarangkalian yang terakhir, yaitu miskin pengalaman sastra.

\section{Pengalaman Baca dan "Wibawa" Guru}

Secara gamblang dapat dikatakan bahwa biasanya peluang dan waktu yang dimiliki para siswa untuk memperoleh berbagai pengalaman baca di luar dinding kelas lebih besar dan lebih banyak dibandingkan dengan para guru mereka yang sudah tenggelam dalam tugas-tugas pengajaran (belum lagi soal survival kehidupan). Keluasan dan keanekaragaman pengalaman dan pengetahuan para siswa dalam hal bacaan di luar dari yang diwajibkan, tidaklah berada dalam wewenang pengawasan sekolah. Kegairahan remaja untuk mencari dan menemukan tidaklah mengenal batas. Demikian pula "nafsu" untuk menaklukkan sesuatu: apakah itu bernama petualangan, keberanian, kecerdasan, atau barangkali bahkan "wibawa" guru mereka. Akan tetapi, sekali lagi, sekaliannya itu ditunjukkan karena hasrat untuk mengukur diri sendiri. Oleh karenaitu, sangatlah keliru jika kita menanggapi sikap demikian dengan cara yang sama seperti halnya menanggapi ancaman terhadap "wibawa" kita. Kekeliruan tanggap demikian akan berakibat fatal-baik bagi kita sendiri maupun dan terlebih lagi bagi anak didik kita jika reaksi kita adalah mematahkan ofensif mereka dengan bersikap defensif di balik apa yang kita yakini sebagai "wibawa" guru. Hal ini disebabkan karena sekalipun mereka tampaknya bersikap menuntut jawaban, pada dasarnya mereka cukup tahu bahwa kita pun makhluk biasa yang serba terbatas. Sebenarnya, jika kita cukup awas dan waspada banyak di antara pertanyaan dan "tantangan" yang dilemparkan itu hanyalah gertak sambal saja. Bahkan tidak jarang, mereka mengajukannya justru untuk menilai, apakah guru mereka tergolong guru yang otorirer, pengecut, ataukah guru yang jujur dan ksatria.

Dalam keadaan sekarang, mungkin sangat 
sulit bagi para guru untuk mengisi kekurangan pengalaman baca mereka di luar bacaan wajib sekolah. Masalah waktu dan keuangan merupakan sekedar dua penghambat yang dialami di mana-manadan sukar dicarikan jalan keluarnya dari lingkaran setan yang semakin menghimpitparaguru. Bagaimanakahkitaharus bersikap dalam "konfrontasi" kita dengan para siswa yang bacaannya serba aneka-ragam itu? Kasus 1: Seorang siswa menyatakan bahwa novel Arjuna Mencari Cinta karya Yudhistira Ardi Nugraha adalah novel pop yang bernilai sastra. Kita sendiri belum pernah membaca novelitu.

Dalam hal demikian, menjawab secara jujur bahwa kita belum membacanya tidaklah menyelesaikan persoalan. Akan tetapi, jika pengakuan jujur itu disertai dengan pertanyaan balik kepada siswa itu (dan kawan-kawannya yang sependapat), sikap demikian akan lebih dihargai oleh para siswa. Yang penting adalah memilih "strategi" yang tepat untuk mengembangkan hubungan itu, yaitu dengan mengajukan pertanyaan yang tepat. Dalam hal inilah pada hakikatnya "wibawa" guru diuji: Dapatkah ia "merasakan" apa yang dituju, apa yang diharapkan oleh para siswanya? Dapatkah kiranya ia menerka "taktik" ofensif para siswa agar ia dapat menemukan "strategi" yang tepat guna menyalurkan hasrat mereka untuk "menang"? Secepat kilat kita mengingatkan diri kita sendiri bahwa (a) kita belum membaca buku itu dan (b) anak-anak sudah berpijak pada minat budaya dan sosial, sedangkan daya pengamatan dan penangkapan mereka sudah kritis setidaknya per definisi demikianlah. Lalu, dengan serta-merta kita mengajukan pertanyaan-balik itu: "Bagaimanakah cerita novel itu?" atau "Apakah isinya?" Kemudian, dengan "lega" hati kita menunggu uraian mereka (sambil sekaligus berpikir keras: "pertanyaan apa selanjutnya yang akan saya ajukan nanti?". Kalau hal ini yang terjadi, tamatlah riwayat "wibawa" guru di tempat itu juga! Mengapa?
Karena apa yang diceriterakan tidaklah penting dalam suatu karya cerita rekaan. Yang menandai sastra/non-sastranya suatu karya adalah cara menceriterakannya. Dengan demikian, pertanyaan yang seharusnya diajukan adalah, "Bagaimana kisahArjuna Mencari Cinta itu disajikan?"

Kaya atau miskinnya pengalaman baca kita tidak primer ditentukan oleh jumlah dan ragam bacaan kita, melainkan oleh kemampuan kita membedakan berbagai ragam cara pengungkapan dan penyajian. Pertanyaan sehubungan dengan "isi" cerita pada dasarnya hanya menelanjangi kemiskinan pengalaman baca kita karena apa yang diceriterakan atau disajikan sebenarnya sangatlah terbatas. Bukankah kita biasa mengatakan bahwa novelnovel Balai Pustaka menyajikan masalah kawin paksa atau pertentangan antara adat dan kemauan individu, pertentangan antara tua dan muda? Dengan kata lain, novel-novel Balai Pustaka mengolah masalah yang itu-itu juga. Akan tetapi, kita tahu bahwa cara penyajian dalam SalahAsuhan, misalnya, berbeda dengan cara penyajian dalam Sitti Nurbaya; cara penyajian dalam Azab dan Sengsara berbeda dengan cara penyajian Darah Muda. Oleh karena itu, tidaklah relevan jika kita mengajukan pertanyaan berkenaan dengan "isi" pada kesempatan pertama.

Kasus 2: Kita sudah membaca Arjuna Mencari Cinta dan beranggapan bahwa novel itu tidak bernilai sastra. Sebaliknya, para siswa menyatakannya sebagai bernilai sastra.

Dalam keadaan demikian sudah dapat dibayangkan bahwa para siswa tidak akan puas jika kita mengakhiri "konfrontasi" dengan memaklumkan putusan kita dengan atau tanpa disertai penalaran yang meyakinkan. Sebagaimana dikemukakan di dalam bagian terdahulu, sastra atau tidaknya suatu karya sangat banyak ditentukan oleh si pembaca sendiri. Dengan kata lain, tentu para siswa mempunyai alasan mereka, mengapa mereka 
menganggap novel itu bernilai sastra - seperti halnya kita mempunyai alasan untuk menyatakannya sebagai tidak bernilai sastra. oleh karena itu, keadilan dapat kita wujudkan dini hari jika kita memberikan kesempatan kepada mereka untuk mempertahankan pendapat mereka: Mengapa novel itu mereka anggap bernilai sastra? dan dari jawaban mereka kita angkat pokok-pokok atau patokan-patokan penalaran mereka untuk kemudian diarahkan sekiranya memang ngawur. Sebaliknya, dalam diskusi dan "perdebatan" itu sangat mungkin terjadi bahwa kita "kalah". Dalam hal demikian, tidak ada salahnya jika kita secara jujur mengakui "kemiskinan" kita' "Kekalahan" demikian tidak mengurangi wibawa kita jika itu yang dicemaskan. Sebaliknya para siswa akan menghargai sikap ksatria ini dan dengan demikian sebilah bambu baru diletakkan dalam titian keakraban gurumurid yang dapat memupuk kepercayaan yang lebih besar baik pada diri kita sebagai pengajar, maupun pada diri mereka sendiri. Kuncinya terletak pada cara kita mengakui "kekalahan" tersebut.Atau, jika ternyata mereka yang keliru cara kita menunjukkan kekeliruan mereka itulah yang penting. Seperti halnya objek yang sedang dibicarakan yaitu novel maka "wibawa" pun tidak ditentukan oleh "isi", melainkan oleh cara menyatakan "isi" itu!

Demikianlah, dalam praktik pengajaran sehari-hari di kelas berbagai situasi timbul yang menantang para guru untuk mereaksi secara cepat-tepat. Kaya atau miskinnya pengalaman baca seseorang memang bersifat nisbi, artinya, tidak dapat diukur dengan skala numerik yang pasti. Pengalaman demikian ditandai oleh kemampuan kita untuk "mengujikan" kembali segala apa yang telah kita serap dan jadikan milik kita dalam suatu proses panjang pembudayaan sejumlah konvensi dalam diri kita : konvensi bahasa, konvensi sastra, konvensi metasastra, dan konvensi budaya itu sendiri. Dalam hal pengalaman baca ini, kuantitas yang kita serap menentukan kuantitas kemungkinan kita untuk menerima sesuatu yang baru.Artinya, jika kita telah menyerap banyak, maka menambah lagi bukanlah soal yang sukar.Akan tetapi, jika serapan kita sedikit, maka untuk menerima yang baru akan menjadi sulit. Sekalipun demikian, jika kita tidak "mengujikan" apa yang kita miliki itu dengan sikap terbuka dan berlapang hati, maka segala "isi" yang kita kandung itu pun akan mandul: ia tidak akan menumbuhkan apresiasi kita, pun tidak merangsang sikap agresif anak didik kita.

\section{Sastra dan Nonsastra}

Dalam bagian ini akan dicoba untuk menggambarkan kemungkinan ketiga dalam pertemuan guru-murid sehubungan dengan pengajaran apresiasi sastra. Pertemuan itu ditandai oleh situasi yang "menantang" guru untuk menjadi hakim: Manakah novel yang bernilai sastra dan mana yang tidak?

Pada hemat saya, cara yang baik untuk "melayani" tantangan demikian adalah mengembalikan pertanyaannya kepada si penanya sedemikian rupa sehingga ia (dan kawan-kawannya yang sependapat) tergerak untuk merumuskan patokan-patokan yang telah dipakai untuk sampai pada penilaiannya. Sangat besar kemungkinannya mereka menemui kesukaran dalam merumuskan penalaran mereka. Dalam hal demikian, yang harus kita lakukan adalah membantu mereka untuk sampai kepada perumusan penalaran mereka. Dalam upaya membantu inilah, peran kita sebagai guru yang "berwibawa" diuji. Dapatkah kita membantu mereka sambil mengoreksi ketidaktepatan atau mungkin kekeliruan pengamatan serta penalaran mereka?

Salah satu cara mempraktekkan upaya ini adalah membandingkan secara langsung dengan penalaran kita sendiri (yang rnenuju pada penilaian bahwa novel yang dibicarakan tidaklah bernilai sastra, misalnya). Secara teoritis, mengemban tugas sebagai "hakim" ini dapat dilaksanakan dengan mengkombinasikan sikap dan carakitamenanggulangi kasus pertama dan 
kasus kedua yang digambarkan di bagian terdahulu. memang tidak mudah. Selain itu, hal itu sangat bergantung pada keadaan kelas sebagai totalitas yang terdiri keanekaragaman. Sekalipun demikian, beberapa patokan umum dapat dipakai sebagai batu loncatan, yang dapat dikembangkan sesuai dengan keadaan kelas masing-masing.

\section{Mencari unsur-unsur yang memper- kaya pengalaman batin dan kehidupan rohani pembacanya.}

Para siswa diminta untuk "mengisahkan" kembali bagian-bagian alinea, dialog, uraian, ataupun tindakan dan peristiwa yang dianggapnya menambah dan memperkaya kepekaan sosial-budayanya, berkenaan dengan hubungan manusia dengan sesama manusia, manusia dengan alam, manusia dengan penciptanya, manusia dengandirinya sendiri, dan manusia dengan masyarakatnya. Saya katakan "kepekaan sosial-budaya" karena halhal itu seringkali tampak "biasa" dan "sehari-

hari", namun di balik "kebiasaan" dan "kesehari-harian" itu tersirat sesuatu yang "baru", yang selama ini belum pernah disadari pembacanya sebagai ada, sebagai hadir dalam pengalaman batin dan rohaninya. Kadangkadang, pengalaman batin sukar dibedakan dari tambahan pengetahuan yang bersifat informatif sekalipun. Dalam hal demikian, maka informasi baru yang kiranya diperoleh pembaca dari bacaannya itu hendaknya diminta supaya dibandingkan dengan informasi yang sama sekiranyaitu diperolehnya dari sebuah buku ilmiah. Contoh: Berbagai jenis tumbuhan yang ada di sekitar tempat akan dibangunnya sebuah surau dalam novel Pergolakan karya Wildan Yatim. Penyajiannya dalam novel tentu sangat berbeda dengan penerangan yang ditemui dalam sebuah buku tentang ilmu tumbuhtumbuhan. salah satu perbedaan yang paling menyolok adalah kenyataan seperti berikut ini.

Dalam novel Pergolakan "keterangan" tersebut berfungsi membina latar yang antara lain berfungsi menggarisbawahi kebulatan tekad dan keuletan tokoh untuk melaksanakan panggilannya. Dengan kata lain latar disana tidak sekedar latar fisik yang statis, melainkan latar yang dinamis, yang membantu suasana dan watak si tokoh. Fungsi demikian tidak ada dalam buku ilmu tumbuh-tumbuhan.

\section{Menunjukkan kecermatan dan kesungguhan penyajian, baik yang menempuh cara ragaan, maupun cara uraian.}

Para siswa diajak mengamati bagianbagian tertentu yang kemudian diikuti terus perkembangan uraian atau ragaanya sehingga memperoleh gambaran jelas tentang penyajian yang cermat dan bersungguh-sungguh. Untuk menerangkan "cermat" dan "sungguh-sungguh" mungkin cara ilustrasi paling efektif. Artinya, apa yang didapati dalam novel dibandingkan dengan cara penyajian yang tidak bersifat sastra, seperti didapati, misalnya, dalam surat kabar. Contoh: pemburuan harimau dalam Harima! Harima! Karya Mochtar Lubis dibandingkan dengan berita lengkap peristiwa tertangkapnya kembali Kusni Kasdut. Dalam mengemukakan ilustrasi demikian tidak saja akan tertonjolkan kecermatan dan kesungguhan penyajian dalam Harimau! Harimau!, melainkan juga "kelainan" pemakaian bahasa dalam sebuah novel sastra dibandingkan dengan berita dalam surat kabar: pilihan katanya 'susunan' kalimatnya, kaitannya dengan penggambaran sebelumnya, makna kata tertentu dalam hubungannya dengan kalimatnya ataupun dengan konteks yang lebih luas dalam karya yang sama.

Penelusuran cara penyajian demikian membutuhkan kecermatan di pihak pembacanya juga sehingga dalam hal ini pengajaran apresiasi sastra memang tidak harus mutlak dipisahkan dari pengajaran bahasa, sekalipun tujuannya berbeda. Salah satu kriterium utama untuk menetapkan kecermatan dan kesungguhan penyajian adalah fungsi 
ragaan dan/atau uraian yang tidak dapat dipisahkan dari penokohan, pengaluran, dan pelataran, yaitu teknik-teknik untuk menampilkan tokoh, peristiwa, dan latar kejadian.

\section{Menunjukkan keutuhan dan kepaduan yang tersaji dalam novel}

Kriterium ini merupakan patokan yang "paling sukar" diajarkan karena menyangkut hakikat karya seni pada umumnya. Jembatan yang pada hemat saya paling praktis untuk ditempuh adalah mengenali titian demi titian dalam jalinan argumentatif. Perlu kiranya ditambahkan bahwa jalinan itu tidak harus atau tidak hanya ditafsirkan dalam arti kausalitas. Dalam hal "mengukur" keutuhan dan kepaduan penyajian, kita lebih memusatkan perhatian kita pada konsekuen tidaknya sesuatu yang sudah dimulai itu dikembangkan dan diselesaikan. Saya ambilkan sebuah contoh yang agak "sukar", yaitu novel Telegam karya Putu Wijaya.

Pembaca yang bertolak dari tradisi membaca novel secara "konvensional" yaitu dengan bekal harapan akan disuguhi "ceritera" yang punya awal dan punya akhir akan bingung dan bertanya-tanya, mengapa novel itu menyajikan "kisahnya" dengan cara yang berantakan tidak ada kesinambungan ceritera demikian kiranya kesan pembaca yang "konvensional" itu. Akan tetapi, jika kita meluangkan waktu dan terutama menyediakan kecermatan serta kesabaran segera akan tampak bahwa "keanehan" novel ini adalah caranya yang sangat biasa dalam menyajikan sesuatu yang terlalu amat biasa pula, tetapi sangatlah tidak biasa disajikan dalam bentuk tertulis, yaitu loncatan-loncatan pikiran dan suara batin seorang (calon) penerima telegram (karena telegram itu baru diterimanya menjelang akhir novel!). Loncatan demi loncatan disajikan dalam novel itu, yang sebagai karya yang menggunakan bahasa tertulis maka mau tidak mau harus dibaca secara linear, yaitu menuruti garis lurus.Tidak adajalinan kausalitas antara loncatan batin yang satu dengan yang lainnya, namun, secara keseluruhan diperoleh kesan bahwa loncatan-loncatanitu secara konsisten disusun sedemikianrupa sehingga membentuk suatu totalitas yang utuh dan padu, diikat oleh sebuah benang halus yang nyaris tidak tampak dalam pembacaan, yaitu kegelisahan dan berbagai pikiran yang berkecamuk dalam diri si tokoh. Cara yang ditempuh pada awal novel dilaksanakan terus secara konsisten, cermat, dan bersungguhsungguh sepanjang novel itu, untuk sampai pada kebulatan dan keutuhan penyajian yang khas.

Jika hendak dicarikan patokan-patokan pembantu dalam menentukan kriterium ini, maka kiranya dua sendi dapat dipertimbangkan, yaitu (a) sendi keseimbangan dan (b) sendi keselarasan.

Sendi yang pertama bertolak dari prinsip perpaduan dua hal atau lebih yang berbeda satu dari lainnya. Contoh tokoh jahat dan tokoh baik. Dalam suatu karya sastra, perpaduan kedua unsur itu menuju keseimbangan. Jika tanpa sebab yang "masuk akal" salah satu diantaranya dimusnahkan, maka penyajian demikian tidak memenuhi syarat untuk disebut sebagai sastra. Contoh, matinya Inge NgikNgok alias Icih dalam novel Sok Nyentrik karya Eddy D. Iskandar, sekali pun penyebabnya kitaketahui.

Berbeda dengan keseimbangan, prinsip keselarasan dibina oleh unsur-unsur yang mirip satu dengan lainnya. Misalnya, dalam suatu novel ada sejumlah tokoh yang mewakili sifat baik dan sejumlah lagi mewakili yang jahat. Proporsi kebaikan dan kejahatan di masingmasing pihak hendaknya jangan dimonopoli ataupun bertumpang-tindih. Prinsip keselarasan mungkin lebih mudah dipercontohkan dengan seni lukis atau seni musik.

Dalam hal musik, misalnya, jika ada nadanada sumbang menyelip secara tidak proporsional misalnya karena seorang penggesek biola tergelincirmenekankanjarinya 
di dawai biola maka totalitas sajian nada menjadi rusak oleh kesumbangan itu.

Dalam hal novel dapat dikemukakan contoh Harimau! Harimau! Karya Mochtar Lubis. Dalam novel tersebut kita dapati sejumlah tokoh yang tergolong baik dan tergolong jahat. Namun, tokoh-tokoh bawahan dalam novel itu tidak menenggelamkan sifat utama masing-masing tokoh protagonis dan antagonis yang terkedepankan yang tergolong baik, menggarisbawahi tokoh Buyung, sedangkan yang tergolong jahat secara simbolis menggarisbawahi kebuasan harimau yang tengah diburu (dan kemudian dimusnahkan). Hubungan fungsional antara unsur-unsur yang membina keseimbangan dan keselarasan itulah yang pada akhirnya mewujudkan keutuhan dan kepaduan karya sastra.

\section{Penutup}

Kertas kerja ini tidak menggariskan patokan-patokan normatif untuk menentukan karya mana yang bernilai sastra. mana yang tidak. Patokan normatif mengundang kegiatan pengamatan yang primer deduktif, yaitu menerapkan begitu saja patokan-patokan 1 'ang diberikan pada karya yang akan dinilai. Dapat dibayangkan bahwa pendekatan demikian menciderai hakikat pengajaran apresiasi sastra. Apalagi jika diingat bahwa pengajaran itu diberikan kepada siswa tingkat lanjutan atas, yang beranjak dari apresiasi yang melibatkan emosionalitas ke minat yang bersifat sosial-budaya.

Apresiasi sastra hanya dapat dilaksanakan atas dasar keakraban si pembaca dengan apa yang dihadapinya. Keakraban itu dapat dibina dan dipupuk, antara lain dan terutama melalui pengenalan langsung dengan karya-karya bersangkutan. Dengan kata lain, pendekatan yang efektif adalah pendekatan yang induktif: membiarkan karya itu berbicara pada pembacanya, menghimbau pembacanya secara langsung. Dalam hal ini, pengalaman bacalah yang perlu dibina, diarahkan, dan dikembangkan. Pada akhirnya, dan secara agak ekstrim dapat dikatakan bahwa bernilai sastra atau tidaknya suatu karya sangatlah bergantung pada kemampuan si pembaca untuk berkomunikasi secara akrab dengan karya yang dihadapinya.

Sehubungan dengan hal tersebut di atas, ketiga patokan yang diberikan dalam kertas kerja ini merupakan sekedar alat bantu untuk mengarahkan cara pendekatan induktif. Untuk para guru, yang beban tugasnya sebagaimana digambarkan di dalam bagian pengantar dan Latar Belakang dan Masalah, patokan-patokan itu workable. Artinya, mereka dapat memanfaatkan tanpa harus terlebih dahulu mengikuti suatu crash program pendidikan guru sastra atau penataran, melainkan justru samasama mempraktekkannya dalam pertemuan guru-murid dengan karya sastra bersangkutan; sama-sama mencari dan menentukan, serta sama-sama mengakrabi sastra.

Kertas kerja ini dilengkapi dengan tiga lampiran, yang masing-masing memuat contoh untuk dijadikan landasan diskusi, sekiranya dirasakan perlu untuk memperjelas beberapa pokok yang dikemukakan di dalam bagianbagian terdahulu.

\section{DAFTAR PUSTAKA}

Departemen Pendidikan dan Kebusayaan.1976. Kurikulum Sekolah Menengah Atas (SMA) 1975: Garisgaris Besar Program Pengajaran. Buku IIDI Bidang Studi: Bahasa Indonesia. Jakarta: BalaiPustaka.

Oemarjati, Boen S. 1978. "Pengajaran Sastra dan Pembinaan Apresiasi Sastra” Kertas Kerja untuk Kongres Bahasa Indonesia III, Jakarta, 28 Oktober-3 November 1978. Jakarta: Pusat Pembinaan dan Pengembangan Bahasa.

Pusat Pembinaan dan Pengembangan Bahasa. 1977/1978. Penelitian Kegiatan 
Apresiasi Sastra Indonesia Murid (SMA) Jawa Barat. Laporan Penelitian oleh Fakultas Keguruan Sastra dan Seni. Institut Keguruan dan Ilmu Pendidikan Bandung, untuk Proyek Penelitian Bahasa dan Sastra Indonesia dan daerah.

Rivai, Sitti Faizah. 1963. "Romah Pitjisan” Skripsi Sarjana Sastra. Jakarta: Fakultas Sastra. Universitas Indonesia 
Rosidi, Ajip. 1969. Ichtisar Sejarah Sastra Indonesia. Bandung:Binatjipta.

Sastrowardojo, Subagio. 1971. Bakat Alam dan Intelektualisme. Jakarta: Pustaka Jaya.

Teeuw, A., Prof. Dr. 1955. Pokok dan Tokoh

II. Jakarta: PT Pembangunan. 